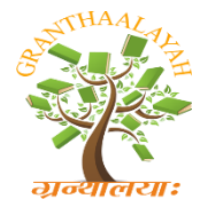

Management

\title{
PRODUCT CHARACTERISTICS THAT INFLUENCE CONSUMER PURCHASING DECISIONS OF SMALL CARS
}

\author{
Dr.Geeta Yadav ${ }^{* 1}$ \\ ${ }^{* 1}$ Assistant Professor, Indira Gandhi University, Meerpur, Rewari, India
}

\begin{abstract}
There are multiple factors, specificities, characteristics, circumstances, environment that affect the buying pattern of an individual. A purchase decision is the result of multiple aspects and factors. A motivated person is ready to act according to the perception of the situation (product or services).There are number of product characteristics which should be consider by consumer before purchase .The present paper seeks to identify the factors that influence the consumer behavior with to small cars. The finding of the study can be helpful to marketers in dealing with the customers in a better way.
\end{abstract}

Keywords: Consumer Motives; Psychological Factors; Consumer Behavior; Passenger Car Segment.

Cite This Article: Dr.Geeta Yadav. (2018). "PRODUCT CHARACTERISTICS THAT INFLUENCE CONSUMER PURCHASING DECISIONS OF SMALL CARS." International Journal of Research - Granthaalayah, 6(1), 463-469.

\section{Introduction}

Consumer behavior might be the following: The mental, emotional and physical activities that people engage in when selecting, purchasing, using and disposing of products and services so as to satisfy needs and desires (Priest, Carter, \& Stat, 2013). It is believed that consumer behaviors to be driven by needs and consumer products could be defined in terms of the needs they fulfilled (Bayton, 1958).

Consumer is the one who consumes the goods and services produced. As such, consumers play a vital role in the economic system of a nation because in the absence of the effective demand that emanates from them, the economy virtually collapses. Customer is a person, company, or other entity which buys goods and services produced by another person, company, or other entity (Durmaz \& Jablonski, 2012).

Consumers with higher social needs may value more prestigious products or services or brand(Solomon, 1983); therefore, recognizing consumer esteem and belongingness needs is an important tool for marketers during the development stage(O'Cass \& Frost, 2002). 


\section{Review of Literature}

The first and probably most vital condition for the emergence of the small car lay in a growing demand scenario for a small and fuel efficient car (Venkataramani, 1990). The small car demand was constituted by India's growing middle class. It is among other factors, the expanding public sector that contributed to the emergence of a sizable middle class that posed increasing consumer demands (D’Costa, 2005).

Additional research exploring the relationship between consumers and their consumption have found that consumers connect more with product or services that hold images that are shared by the consumers' reference group (Escalas \& Bettman, 2005) thus fulfilling the need to belong; and that product or brand are used to seek social approval in their respective environments (Kuester, Hess, Hinkel, \& Young, 2007).

The other reason for the emergence of the small car was rooted in the situation and beginning of de-regulation of the Indian economy in the late 1980s (D'Costa, 2005). For Indian companies, the liberalization implied the emergence of international competition in what used to be an entirely protected market. The liberalization and India's new industrial policy not only had a strong impact on the supply side for the production of small cars; equally important was the impact the liberalization had on the demand side for small cars in India.

In the early $21^{\text {st }}$ century, Indian small car segment continued to develop and grow stronger. In 2004, India became "the fastest growing large market for passenger cars in the world" (The Economist Intelligence Unit, 2006). It was the highly price sensitive, lower market segments (especially the Mini (A1) and Compact (A2) Segment that benefited strongly from the reform driven economic growth and particularly fiscal and monetary reforms. Also, the reform of the banking system, low interest rates and the continued reduction of excise duty rendered vehicle financing easier and stimulated entry level demand (Nair, 2006).

\section{Influence of Various Product Characteristics on Purchase}

Based on literature review, following list of car attributes are formulated that may influence the small car purchase.

Table 3.1: Product Characteristics

\begin{tabular}{|l|l|}
\hline Factors & Variable name \\
\hline Fuel efficiency & Fuel efficiency \\
\hline Pick up & Pick up \\
\hline Compact size & Size \\
\hline Price (on-road) & Price \\
\hline Vehicle lifespan (life) & Lifespan \\
\hline Resale Value & Resale \\
\hline Safety Features & Safety \\
\hline Environmental friendliness & Environment friendly \\
\hline Personal assistance services (on call/ emergency) & Service Assistance \\
\hline Use of alternative fuel technologies such as electric power, solar & Alt. fuel \\
\hline
\end{tabular}




\begin{tabular}{|l|l|}
\hline power & \\
\hline Vehicle styling/exterior & Exterior \\
\hline & Interior \\
\hline Payment option / Interest Rates & Plug in \\
\hline Spare part availability & Payment \\
\hline Discount and exchange offers & Spare part \\
\hline Brand Image & Offers \\
\hline Advertising and sales promotion activities & Brand image \\
\hline Dealer / service center location & Advt. promotion \\
\hline Number of model available & Dealer location \\
\hline Dealer Reputation & Model \\
\hline Dealer after sales service & Dealer reputation \\
\hline
\end{tabular}

These product characteristics are important to help in decision making of buying a car.

These features of cars are considered in our research. A structured questionnaire is used to collect data on above mentioned factors in a 5-point importance scale, where 5='very important' to $1=$ 'Least important'. To test the influence we formulated following hypothesis.

\section{Data Collection}

The data is primary in nature. The data is collected from small car owner of Haryana district of India. The instrument used for collection of data is "questionnaire".

\section{Hypothesis: All identified product characteristics are important for the small car purchase}

\section{Scale Reliability}

Summated scales are often used in survey instruments to probe underlying constructs that the researcher wants to measure. These may consist of indexed responses to dichotomous or multipoint questionnaires, which are later summed to arrive at a resultant score associated with a particular respondent. Reliability comes to the forefront when variables developed from summated scales are used as predictor components in objective models. Since summated scales are an assembly of interrelated items designed to measure underlying constructs, it is very important to know whether the same set of items would elicit the same responses if the same questions are recast and re-administered to the same respondents.

One of the most popular reliability statistics in use today is Cronbach's alpha (Cronbach, 1951)

To test the reliability, the prepared questionnaire was demonstrated to 25 respondents consisting students and shoppers. The reliability of the developed questionnaire was tested by deploying the statistical test 'Cronbach's alpha' to the responses received from 25 respondents selected randomly. 
Table 5.1: Reliabilities of Scale

\begin{tabular}{|l|l|l|l|}
\hline \multicolumn{2}{|l|}{ Case Processing Summary } & N & $\%$ \\
\hline \multirow{3}{*}{ Cases } & Valid $^{\mid}$ & 600 & 100.0 \\
\cline { 2 - 4 } & Excluded $^{\mathrm{a}}$ & 0 & .0 \\
\cline { 2 - 4 } & Total & 600 & 100.0 \\
\hline
\end{tabular}

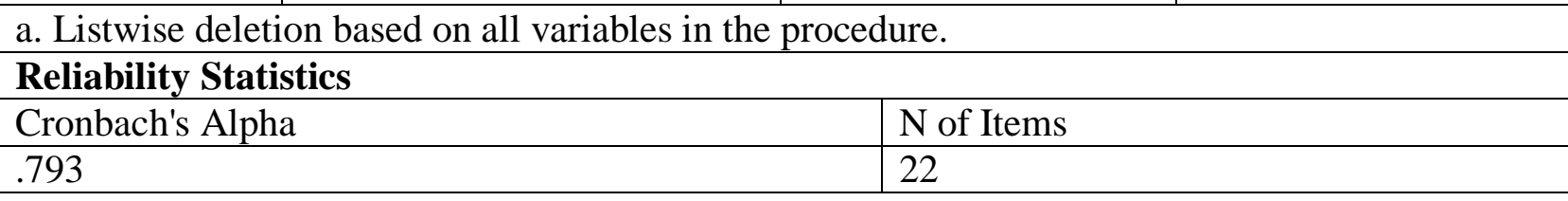

\section{Item-Total Statistics}

\begin{tabular}{|l|l|l|l|l|}
\hline & $\begin{array}{l}\text { Scale Mean if } \\
\text { Item Deleted }\end{array}$ & $\begin{array}{l}\text { Scale Variance } \\
\text { if Item Deleted }\end{array}$ & $\begin{array}{l}\text { Corrected Item- } \\
\text { Total } \\
\text { Correlation }\end{array}$ & $\begin{array}{l}\text { Cronbach's } \\
\text { Alpha if Item } \\
\text { Deleted }\end{array}$ \\
\hline Fuel_eff & 79.3583 & 104.381 & .159 & .794 \\
\hline Pick_up & 79.8100 & 99.483 & .414 & .782 \\
\hline Size & 80.3417 & 99.945 & .284 & .789 \\
\hline Price & 79.9783 & 99.430 & .344 & .785 \\
\hline Lifespan & 79.6850 & 102.447 & .248 & .790 \\
\hline Resale & 80.0367 & 102.386 & .206 & .792 \\
\hline Safety & 79.5550 & 98.882 & .442 & .781 \\
\hline Env_friend & 79.8033 & 100.429 & .315 & .787 \\
\hline Srv_Assistance & 80.3333 & 96.767 & .512 & .776 \\
\hline Alt_fuel & 80.8583 & 96.699 & .369 & .784 \\
\hline Exterior & 80.0583 & 99.457 & .319 & .786 \\
\hline Interior & 79.8533 & 98.760 & .356 & .784 \\
\hline Plug_in & 80.3083 & 98.838 & .313 & .787 \\
\hline Payment & 80.3133 & 99.224 & .345 & .785 \\
\hline Spare_part & 79.7467 & 100.477 & .303 & .787 \\
\hline Offers & 80.1350 & 98.661 & .378 & .783 \\
\hline B_image & 79.8850 & 99.434 & .372 & .784 \\
\hline Avt_prmtion & 80.5433 & 96.142 & .392 & .782 \\
\hline Dealer_loc & 80.2867 & 98.669 & .341 & .785 \\
\hline Num_Model & 80.4467 & 98.391 & .313 & .787 \\
\hline Dealer_reput & 80.1883 & 97.726 & .391 & .782 \\
\hline After_sale & 79.8500 & 96.912 & .424 & .780 \\
\hline
\end{tabular}

Table presents reliability of scales measured in Cronbach's alphas. The Cronbach's alpha covering the overall responses has exceeded the reliability estimates $(>=0.70)$ recommended by Nunnally (1967), which is considered a good sign of reliability of the questionnaire. Table describes the reliability analysis of the scale corresponds to each variable

To test the hypothesis one sample ' $t$ ' test is applied. The one-sample t-test is used to determine whether a sample comes from a population with a specific mean. This population mean is not always known, but is sometimes hypothesized. Your dependent variable should be measured at 
the interval or ratio level (i.e., continuous). Examples of variables that meet this criterion include revision time (measured in hours), intelligence (measured using IQ score), exam performance (measured from 0 to 100), weight (measured in $\mathrm{kg}$ ), and so forth.

The data should be independent (i.e., not correlated/related), which means that there is no relationship between the observations. This is more of a study design issue than something you can test for, but it is an important assumption of the one-sample t-test. There should be no significant outliers. Outliers are data points within your data that do not follow the usual pattern. The problem with outliers is that they can have a negative effect on the one-sample ttest, reducing the accuracy of your results.

By default, SPSS uses 95\% confidence intervals (Labeled as the Confidence Interval Percentage in SPSS). This equates to declaring statistical significance at the $p<.05$ level. For this research, keep the default $95 \%$ confidence intervals.

Table 5.2: One-Sample Result

\section{One-Sample Statistics}

\begin{tabular}{|l|l|l|l|l|}
\hline & N & Mean & Std. Deviation & Std. Error Mean \\
\hline Fuel_eff & 600 & 4.5167 & .85104 & .03474 \\
\hline Pick_up & 600 & 4.0650 & .91406 & .03732 \\
\hline Size & 600 & 3.5333 & 1.15807 & .04728 \\
\hline Price & 600 & 3.8967 & 1.06515 & .04348 \\
\hline Lifespan & 600 & 4.1900 & .91394 & .03731 \\
\hline Resale & 600 & 3.8383 & 1.05073 & .04290 \\
\hline Safety & 600 & 4.3200 & .92504 & .03776 \\
\hline Env_friend & 600 & 4.0717 & 1.01402 & .04140 \\
\hline Srv_Assistance & 600 & 3.5417 & 1.00163 & .04089 \\
\hline Alt_fuel & 600 & 3.0167 & 1.30354 & .05322 \\
\hline Exterior & 600 & 3.8167 & 1.12331 & .04586 \\
\hline Interior & 600 & 4.0217 & 1.11202 & .04540 \\
\hline Plug_in & 600 & 3.5667 & 1.21299 & .04952 \\
\hline Payment & 600 & 3.5617 & 1.08543 & .04431 \\
\hline Spare_part & 600 & 4.1283 & 1.03778 & .04237 \\
\hline Offers & 600 & 3.7400 & 1.07284 & .04380 \\
\hline B_image & 600 & 3.9900 & 1.00078 & .04086 \\
\hline Avt_prmtion & 600 & 3.3317 & 1.30429 & .05325 \\
\hline Dealer_loc & 600 & 3.5883 & 1.15950 & .04734 \\
\hline Num_Model & 600 & 3.4283 & 1.26657 & .05171 \\
\hline Dealer_reput & 600 & 3.6867 & 1.14193 & .04662 \\
\hline After_sale & 600 & 4.0250 & 1.15322 & .04708 \\
\hline One-Sample Test & & & & \\
\hline & & & & \\
\hline & & & & \\
\hline & & & & \\
\hline & & & & \\
\hline & & & & \\
\hline & & & & \\
\hline & & & & \\
\hline & & & & \\
\hline
\end{tabular}




\begin{tabular}{|c|c|c|c|c|c|c|}
\hline & \multicolumn{6}{|c|}{ Test Value $=4$} \\
\hline & \multirow[b]{2}{*}{$\mathbf{t}$} & \multirow[b]{2}{*}{ df } & \multirow[b]{2}{*}{ Sig. (2-tailed } & \multirow{2}{*}{$\begin{array}{l}\text { Mean } \\
\text { Difference }\end{array}$} & \multicolumn{2}{|c|}{$\begin{array}{l}95 \% \text { Confidence Interval of } \\
\text { the Difference }\end{array}$} \\
\hline & & & & & Lower & Upper \\
\hline Fuel_eff & 14.871 & 599 & .000 & .51667 & .4484 & .5849 \\
\hline Pick_up & 1.742 & 599 & .082 & .06500 & -.0083 & .1383 \\
\hline Size & -9.871 & 599 & .000 & -.46667 & -.5595 & -.3738 \\
\hline Price & -2.376 & 599 & .018 & -.10333 & -.1887 & -.0179 \\
\hline Lifespan & 5.092 & 599 & .000 & .19000 & .1167 & .2633 \\
\hline Resale & -3.769 & 599 & .000 & -.16167 & -.2459 & -.0774 \\
\hline Safety & 8.474 & 599 & .000 & .32000 & .2458 & .3942 \\
\hline Env_friend & 1.731 & 599 & .084 & .07167 & -.0096 & .1530 \\
\hline Srv_Assistance & -11.209 & 599 & .000 & -.45833 & -.5386 & -.3780 \\
\hline Alt_fuel & -18.478 & 599 & .000 & -.98333 & -1.0878 & -.8788 \\
\hline Exterior & -3.998 & 599 & .000 & -.18333 & -.2734 & -.0933 \\
\hline Interior & .477 & 599 & .633 & .02167 & -.0675 & .1108 \\
\hline Plug_in & -8.751 & 599 & .000 & -.43333 & -.5306 & -.3361 \\
\hline Payment & -9.892 & 599 & .000 & -.43833 & -.5254 & -.3513 \\
\hline Spare_part & 3.029 & 599 & .003 & .12833 & .0451 & .2115 \\
\hline Offers & -5.936 & 599 & .000 & -.26000 & -.3460 & -.1740 \\
\hline B_image & -.245 & 599 & .807 & -.01000 & -.0902 & .0702 \\
\hline Avt_prmtion & -12.551 & 599 & .000 & -.66833 & -.7729 & -.5638 \\
\hline Dealer_loc & -8.697 & 599 & .000 & -.41167 & -.5046 & -.3187 \\
\hline Num_Model & -11.056 & 599 & .000 & -.57167 & -.6732 & -.4701 \\
\hline Dealer_reput & -6.721 & 599 & .000 & -.31333 & -.4049 & -.2218 \\
\hline After_sale & .531 & 599 & .596 & .02500 & -.0675 & .1175 \\
\hline
\end{tabular}

\section{Interpretation}

Table presented above with the observed $t$-value ("t" column), the degrees of freedom ("df"), and the statistical significance (p-value, 2-tailed) of the one-sample t-test. The t-value is positive and $p<.05$ for dimensions like Fuel efficiency, Vehicle Life span, on road Safety, Availability of spare. The means analysis also revealed that all these characteristics are highly rated by consumers as the population means are statistically different. Hence we can reject the null hypothesis. Small car customers give importance to car life value, its fuel efficiency, safety features and ease of the availability of spare parts.

\section{Conclusion}

From the above study it is found out that the hypothesis taken reject in the study on the sample of population. Small car customers give importance to car life value, its fuel efficiency, safety features and ease of the availability of spare parts. According to our hypothesis we identified product characteristics are important for the small car purchase. But small car customers give importance to some factors. 


\section{References}

[1] Bayton, J. (1958). Motivation, cognition, learning - basic factors in consumer behavior. American Marketing Association, Vol.22 (3), 282-289.

[2] Cronbach, L. J. (1951). Coefficient alpha and the internal structure of test. Psychometrika, Vol. $22(3), 297-334$.

[3] D'Costa, A. P. (2005). The Long March to Capitalism - Embourgeoisement, Internationalisation and Industrial Transformation in India. . Palgrave: Houndsmills.

[4] Durmaz, Y., \& Jablonski, S. (2012). Integrated Approach to Factors Affecting Consumers Purchase Behavior in Poland and an Empirical Study. Global Journal of Management and Business Research (GJMBR), Vol. 12 (15)

[5] Escalas, J., \& Bettman, J. (2005). Self-construal, reference groups, and brand meaning. . Journal of Consumer Research, Vol. 32, , 378-389.

[6] Kuester, S., Hess, S., Hinkel, J., \& Young, J. (2007). Brands as means of self-expression: A cross- cultural study. . Australia \& New Zealand Marketing Academy, Dunedin, New Zealand. , 1670-1677

[7] Nair, J. (2006). Market Expansion Strategies of Maruti Udyog. Hyderabad: ICFAI Knowledge Centre, Case Study distributed by European Case Clearing House, England and USA.

[8] Nunnally, J. C. (1967). Psychometric Theory. New York: McGraw-Hill

[9] O'Cass, A., \& Frost, H. (2002). Status brands: Examining the effects of non-product-related brand associations on status and conspicuous consumption. . Journal of Product \& Brand Management, Vol. 11 (2), 67-88.

[10] Priest, J., Carter, S., \& Stat, D. (2013). Consumer Behavior. United Kingdom.: Edinburgh Business School Press.

[11] Solomon, M. R. (2004). Consumer Behavior. Buying, Having, and Being (6th ed.) . Upper Saddle River, New Jerssey: Pearson Prentice Hall.

[12] The Economist Intelligence Unit. (2006, December). Industry Forecast.

[13] Venkataramani, R. (1990). Japan enters Indian Industry: The Maruti-Suzuki Joint Venture. New Delhi: Radiant Publishers

*Corresponding author.

E-mail address: geeta.yadav4@ gmail.com 